DOI:10.17951/h.2017.51.4.289

\begin{tabular}{lcc}
\hline \multicolumn{3}{c}{ A N N A L E S } \\
UNIVERSITATIS MARIAE CURIE-SKŁODOWSKA \\
LUBLIN - POLONIA \\
VOL. LI, 4 & SECTIOH H \\
\hline
\end{tabular}

Berlin School of Economics and Law. Department of Business and Economics

\author{
WOJCIECH STILLER
}

wojciech.stiller@hwr-berlin.de

\title{
Designing and Displaying the Income Tax Scale under Progressivity
}

Kształtowanie i zobrazowanie progresywnej skali podatkowej

Keywords: average tax rate; bubbles; joint taxation; marginal tax rate; progressivity; tax scale

Slowa kluczowe: krańcowa stopa podatkowa; progresywna skala podatkowa; średnia stopa podatkowa; wspólne rozliczenie małżonków

JEL Code: H2; H24; K34

\section{Introduction}

The personal income tax is usually progressive and based on a marginal tax rate (MTR) that increases in steps [Johansen, 1965, p. 213]. Such a tax scale implies rapid hikes of the MTR and thus break points on the average tax rate (ATR) curve. In some tax systems, tax privileges in the form of the basic allowance or a reduced tax rate are phased out and thus not provided for a higher income. This leads to an increased MTR within the interval of the expiring tax allowance (the so-called "bubble").

The purpose of this article is to present different approaches regarding the design of a progressive tax function (Section 1). Against this background, the German tax scale is outlined as an example of a linear increasing MTR (Section 2). Moreover, the Polish tax scale is analysed by taking into consideration the introduced MTR bubbles (Section 3). The following Sections 4 and 5 deepen this issue by presenting the bubbles of the British and the US tax scale, as well as raising the problem of the joint taxation under such a design of the tax function. 


\section{Design of a progressive tax}

A tax is deemed to be progressive if the tax amount increases overproportionately in relation to income: $x_{i}<x_{j} \Rightarrow \frac{T\left(x_{i}\right)}{x_{i}}<\frac{T\left(x_{j}\right)}{x_{j}}$, whereby $x$ denotes income and $T(x)$ the tax amount for an income of $x$. The progressivity implies that the increasing ATR is lower than the MTR: $\operatorname{ATR}(x)<M T R(x)$. This is usually fulfilled, since in most countries the tax scale is based on a MTR that increases in steps for the consecutive income tax brackets [Seidl, Pogorelskiy, Traub, 2013, p. 8; Endres, Spengel, 2015, p. 76; IBFD, 2016b].

This so-called traditional income tax formula, leads to rapid hikes of the MTR and thus break points of the ATR curve at the upper thresholds of the tax brackets. This drawback has attracted the attention of economists and mathematicians for more than a century now [Voigt, 1912; Seidl, Topritzhofer, Grafendorfer, 1970] and is presented (see Figure 1) using the following baseline tax scale:

$$
T(x)=\left\{\begin{array}{lr}
0, & x \leq x_{1} \\
M T R_{1} \cdot\left(x-x_{1}\right), & x_{1}<x \leq x_{2} \\
M T R_{2} \cdot\left(x-x_{2}\right)+T\left(x_{2}\right), & x>x_{2}
\end{array}\right.
$$

$x_{1}$ is the basic allowance, after which the $M T R_{1}$ is applied to an income $x \in\left(x_{1} ; x_{2}\right)$. The income exceeding the upper limit of $x_{2}$ is taxed at a higher $M T R_{2}$.

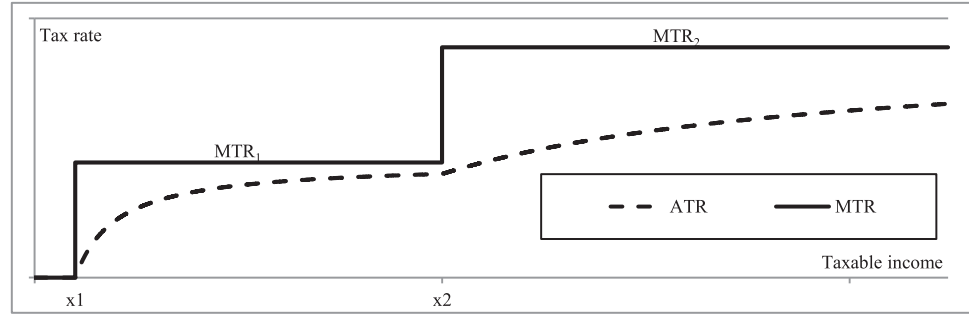

Figure 1. Average and marginal tax rate - baseline tax scale

Source: own diagram based on the tax scale $T(x)$.

In order to smooth the ATR function, further tax brackets $\left(x_{1} ; x_{\text {new }}\right)$ and $\left(x_{n e w} ; x_{2}\right)$ could be introduced. The reduction of the lowest MTR $\left(M T R_{1} \downarrow\right)$ on an income $x \in\left(x_{1} ; x_{\text {new }}\right)$ at the same time would smooth the rapid tax increase for an income exceeding the basic allowance $\left(x_{1}\right)$. The tax scale would be extended to:

$$
T(x)^{\Delta}=\left\{\begin{array}{lr}
0, & x \leq x_{1} \\
M T R_{1} \cdot\left(x-x_{1}\right), & x_{1}<x \leq x_{\text {new }} \\
M T R_{\text {new }} \cdot\left(x-x_{\text {new }}\right)+T\left(x_{\text {new }}\right)^{\Delta}, & x_{\text {new }}<x \leq x_{2} \\
M T R_{2} \cdot\left(x-x_{2}\right)+T\left(x_{2}\right)^{\Delta}, & x>x_{2}
\end{array}\right.
$$

The amount of the new threshold $x_{\text {new }}$ as well as the level of the additional MTR $\left(M T R_{\text {new }} \in\left(M T R_{1} \downarrow ; M T R_{2}\right)\right)$ can be varied for the purpose of the revenue neutral amendment (see Figure 2). 


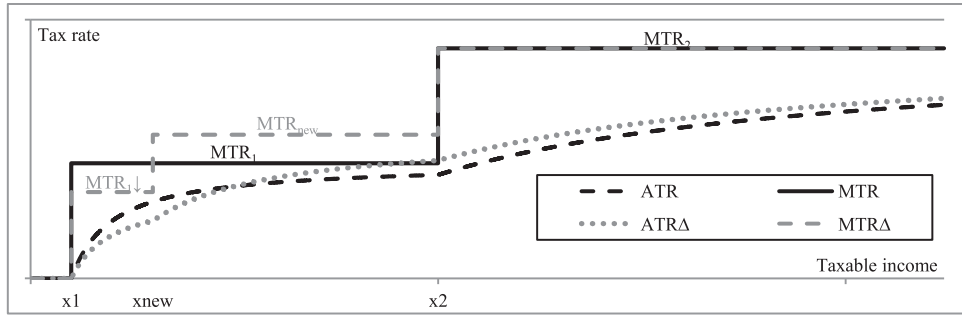

Figure 2. Average and marginal tax rates - baseline and extended tax scale

Source: own diagram based on the tax scales $T(x)$ and $T(x)^{\Delta}$.

Nevertheless, the gradual increase of the MTR - tax bracket by tax bracket causes breakpoints of the ATR function. These can be avoided by means of a linear function. Let us assume that the ATR should increase linearly within the tax bracket $\left(x_{1} ; x_{2}\right)$, whereby $\frac{T(x)}{x}=a \cdot x+b$. In order to avoid breakpoints at the extreme values of the given interval, the ATR linear function should connect the ATR values $\operatorname{ATR}\left(x_{1}\right)=0$ and $\operatorname{ATR}\left(x_{2}\right)=\frac{M T R_{1} \cdot\left(x_{2}-x_{1}\right)}{x_{2}}$ of the baseline tax scale (see Figure 1). Based upon these two points of intersection, the following equation is calculated $\operatorname{ATR}(x)=\frac{T(x)}{x}=\frac{M T R_{1}}{x_{2}} \cdot x-\frac{M T R_{1} \cdot x_{1}}{x_{2}}$. The derived tax function has the form $T(x)=\frac{M T R_{1}}{x_{2}} \cdot x^{2} \frac{M T R_{1} \cdot x_{1}}{x_{2}} x$ and the adjusted tax scale is as follows (see Figure 3 ):

$$
T(x)^{\circ}=\left\{\begin{array}{lr}
0, & x \leq x_{1} \\
\frac{M T R_{1}}{x_{2}} \cdot x \cdot\left(x-x_{1}\right), & x_{1}<x \leq x_{2} \\
M T R_{2} \cdot\left(x-x_{2}\right)+T\left(x_{2}\right)^{\circ}, & x>x_{2}
\end{array}\right.
$$

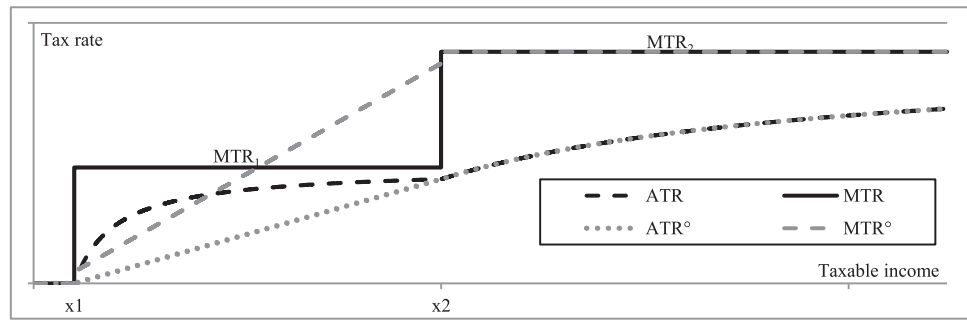

Figure 3. Average and marginal tax rates - baseline and adjusted for ATR tax scale Source: own diagram based on the tax scales $T(x)$ and $T(x)^{\circ}$.

After implementing the above formula, the ATR function has a smoother curve shape than under the baseline tax scale. However, it could still be argued that there are some rapid hikes of the MTR at the point $x_{1}$ as well as $x_{2}$. To address this issue, a linear increasing MTR function for the tax bracket $\left(x_{1} ; x_{2}\right)$ can be determined that connects the points $\operatorname{MTR}\left(x_{1}\right)=0$ and $\operatorname{MTR}\left(x_{2}\right)=M T R_{2}$ of the baseline tax scale. From 
the respective calculated function $M T R(x)=\frac{d T(x)}{d x}=\frac{M T R_{2}}{x_{2}-x_{1}} \cdot x-\frac{M T R_{2} \cdot x_{1}}{x_{2}-x_{1}}$ the following tax function can be derived $T(x)=\int \frac{d T(x)}{d x} d x=\frac{0.5 \cdot M T R_{2}}{x_{2}-x_{1}} \cdot x^{2}-\frac{M T R_{2} \cdot x_{1}-x_{1}}{x_{2}-x_{1}} \cdot x+C$. Based on the basic allowance $x_{1}$, which implies $T\left(x_{1}\right)=0$ the constant $C$ can be determined, whereby the complete tax function is described as follows (see Figure 4):

$$
T(x)^{*}=\left\{\begin{array}{lr}
0, & x \leq x_{1} \\
\frac{M T R_{2}}{x_{2}-x_{1}} \cdot\left(0.5 \cdot x^{2}-x_{1} \cdot x+0.5 \cdot x_{1}{ }^{2}\right), & x_{1}<x \leq x_{2} \\
M T R_{2} \cdot\left(x-x_{2}\right)+T\left(x_{2}\right)^{*}, & x>x_{2}
\end{array}\right.
$$

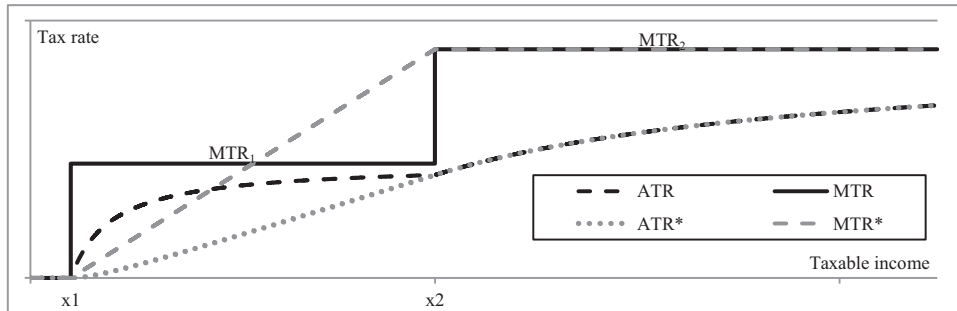

Figure 4. Average and marginal tax rates - baseline and adjusted for MTR tax scale Source: own diagram based on the tax scales $T(x)$ and $T(x)^{*}$.

The above presented adjustments of the tax scale provide an instrument for the legislator when designing a progressive tax scale.

\section{German personal income tax scale}

The German Tax Reform Act of 1990 introduced the linear increasing marginal tax rate to eliminate the rapid hikes of the MTR [Deutscher Bundestag, 1988, p. 10, 149] that appear under the traditional income tax formula (see Figure 1). Table 1 presents the German tax scale for 2016 and 2017. 
Pobrane z czasopisma Annales $\mathrm{H}$ - Oeconomia http://oeconomia.annales.umcs.pl

Data: 26/04/2023 12:10:27

DESIGNING AND DISPLAYING THE INCOME TAX SCALE UNDER PROGRESSIVITY

Table 1. German personal income tax scale

\begin{tabular}{|c|c|c|c|c|c|}
\hline \multicolumn{3}{|c|}{ Tax brackets $[\epsilon]$} & \multirow[t]{2}{*}{$\begin{array}{c}\text { Tax amount } \\
T(x)\end{array}$} & \multirow{2}{*}{$\begin{array}{c}\begin{array}{c}\text { Average tax rate } \\
\text { (ATR) }\end{array} \\
\frac{T(x)}{x} \\
\text { Progressivity } \\
{\left[\begin{array}{c}\text { YES if } \frac{d \frac{T(x)}{x}}{d x}>0\end{array}\right.}\end{array}$} & \multirow{2}{*}{$\begin{array}{l}\text { Marginal tax rate } \\
\quad \text { (MTR) } \\
\frac{d T(x)}{d x}\end{array}$} \\
\hline \multicolumn{2}{|c|}{ from } & up to & & & \\
\hline \multicolumn{6}{|c|}{ Legal status 2016} \\
\hline \multicolumn{2}{|c|}{0} & 8,652 & 0 & $0 \%$ & $0 \%$ \\
\hline \multicolumn{2}{|c|}{8,653} & 13,669 & $(993.62 \cdot y+1,400) \cdot y^{a}$ & $\begin{array}{c}(0 \% ; 7 \%)^{b} \\
{[Y E S]}\end{array}$ & $(14 \% ; 24 \%)^{c}$ \\
\hline \multicolumn{2}{|c|}{13,670} & 53,665 & $(225.4 \cdot z+2,397) \cdot z+952.48^{d}$ & $\begin{array}{c}\langle 7 \% ; 26 \%\rangle^{\mathrm{e}} \\
{[Y E S]}\end{array}$ & $\langle 24 \% ; 42 \%\rangle^{\mathrm{f}}$ \\
\hline \multicolumn{2}{|c|}{53,666} & 254,446 & $0,42 \cdot x-8,394.14$ & $\begin{array}{c}(26 \% ; 39 \%)^{g} \\
{[Y E S]}\end{array}$ & $42 \%$ \\
\hline \multicolumn{2}{|c|}{254,447} & $\infty$ & $0,45 \cdot x-16,027.52$ & $\begin{array}{c}\langle 39 \% ; 45 \%)^{\mathrm{h}} \\
{[Y E S]}\end{array}$ & $45 \%$ \\
\hline \multicolumn{6}{|c|}{ Legal status 2017} \\
\hline \multicolumn{2}{|c|}{0} & 8,820 & 0 & $0 \%$ & $0 \%$ \\
\hline \multicolumn{2}{|c|}{8,821} & 13,769 & $(1.007 .27 \cdot y+1,400) \cdot y^{i}$ & $\begin{array}{c}(0 \% ; 7 \%)^{j} \\
{[Y E S]}\end{array}$ & $(14 \% ; 24 \%)^{\mathrm{k}}$ \\
\hline \multicolumn{2}{|c|}{13,770} & 54,057 & $(223.76 \cdot z+2,397) \cdot z+939.57^{1}$ & $\begin{array}{c}\langle 7 \% ; 26 \%\rangle^{\mathrm{m}} \\
{[Y E S]}\end{array}$ & $\langle 24 \% ; 42 \%)^{n}$ \\
\hline \multicolumn{2}{|c|}{54,058} & 256,303 & $0,42 \cdot x-8,475.44$ & $\begin{array}{c}(26 \% ; 39 \%)^{\circ} \\
{[Y E S]}\end{array}$ & $42 \%$ \\
\hline \multicolumn{2}{|c|}{256,304} & $\infty$ & $0,45 \cdot x-16,164.53$ & $\begin{array}{c}\langle 39 \% ; 45 \%)^{\mathrm{p}} \\
{[\text { YES }]}\end{array}$ & $45 \%$ \\
\hline \multicolumn{6}{|c|}{$\begin{array}{l}\text { According to } \S 32 \mathrm{a} \text { para. } 1 \text { of the German Personal Income Tax Act } y=\frac{x-8,652}{10.000} \text {, so that the tax function can be } \\
\text { presented as follows } T(x)=\frac{993.62 \cdot x^{2}-3,193,600.48 \cdot x-46,748,484,323.52}{10^{8}}\end{array}$} \\
\hline $\mathrm{b}$ & \multicolumn{5}{|c|}{$\begin{array}{l}\text { Based on the formula } \frac{T(x)}{x}=\frac{993.62 \cdot x-3,193,600.48-\frac{46,748,484,323.52}{x}}{10^{8}} \text {, which is derived from the tax function } T(x) \text {, presented } \\
\text { under }^{\text {a }} \text {. }\end{array}$} \\
\hline $\mathrm{c}$ & \multicolumn{5}{|c|}{ Based on the formula $\frac{d T(x)}{d x}=\frac{1,987.24 \cdot x-3,193,600.48}{10^{8}}$, which is a derivative of the tax function $T(x)$, presented under ${ }^{\mathrm{a}}$. } \\
\hline d & \multicolumn{5}{|c|}{$\begin{array}{l}\text { According to } \S 32 \text { a para. } 1 \text { of the German Personal Income Tax Act } z=\frac{x-13,669}{10.000} \text {, so that the tax function can be } \\
\text { presented as follows } T(x)=\frac{225.40 \cdot x^{2}+17,808,014.8 \cdot x-190,283,842,150.6}{10^{8}} \text {. }\end{array}$} \\
\hline e & \multicolumn{5}{|c|}{$\begin{array}{l}\text { Based on the formula } \frac{T(x)}{x}=\frac{225.4 \cdot x+17,808,014.8-\frac{190,283,842,150.6}{x}}{10^{8}} \text {, which is derived from the tax function } T(x) \text {, presented } \\
\text { under }{ }^{\mathrm{d}} \text {. }\end{array}$} \\
\hline $\mathrm{f}$ & \multicolumn{5}{|c|}{ Based on the formula $\frac{\Delta T(x)}{\Delta x}=\frac{450.8 \cdot x+17,808,014.8}{10^{8}}$, which is a derivative of the tax function $T(x$} \\
\hline $\mathrm{g} / \mathrm{h}$ & \multicolumn{5}{|c|}{ Based on the formula $\frac{T(x)}{x}=42 \%-\frac{8,394.14}{x} . /$ Based on the formula $\frac{T(x)}{x}=45 \%-\frac{16,027.52}{x}$. } \\
\hline i & \multicolumn{5}{|c|}{$\begin{array}{l}\text { According to } \S 32 \text { a para. } 1 \text { of the German Personal Income Tax Act } y=\frac{x-8,820}{10.000} \text {, so that the tax function can be } \\
\text { presented as follows } T(x)=\frac{1,007.27 \cdot x^{2}-3,768,242.8 \cdot x-45,122,049,252}{10^{8}}\end{array}$} \\
\hline J & \multicolumn{5}{|c|}{$\begin{array}{l}\text { Based on the formula } \frac{T(x)}{x}=\frac{1,007.27 \cdot x-3,768,242.8-\frac{45,122,049,252}{x}}{10^{8}} \text {, which is derived from the tax function } T(x) \text {, presented } \\
\text { under }{ }^{\mathrm{i}} \text {. }\end{array}$} \\
\hline $\mathrm{k}$ & \multicolumn{5}{|c|}{ Based on the formula $\frac{d T(x)}{d x}=\frac{2,014.54 \cdot x-3,768,242.8}{10^{8}}$, which is a derivative of the tax function $T(x)$, presented under ${ }^{\text {i. }}$. } \\
\hline 1 & \multicolumn{5}{|c|}{$\begin{array}{l}\text { According to } \S 32 \text { a para. } 1 \text { of the German Personal Income Tax Act } z=\frac{x-13,769}{10.000} \text {, so that the tax function can be } \\
\text { presented as follows } T(x)=\frac{223.76 \cdot x^{2}+17,808,097.12 \cdot x-193,664,309,622.64}{10^{8}} \text {. }\end{array}$} \\
\hline $\mathrm{m}$ & \multicolumn{5}{|c|}{$\begin{array}{l}\text { Based on the formula } \frac{T(x)}{x}=\frac{223.76 \cdot x+17,808,097.12-\frac{193,664,309,622.64}{x}}{10^{8}} \text {, which is derived from the tax function } T(x) \text {, } \\
\text { presented under } \text { ? }\end{array}$} \\
\hline n & \multirow{2}{*}{\multicolumn{5}{|c|}{$\begin{array}{l}\text { Based on the formula } \frac{d T(x)}{d x}=\frac{447.52 \cdot x+17,808,097.12}{10^{8}} \text {, which is derived from the tax function } T(x \\
\text { Based on the formula } \frac{T(x)}{x}=42 \%-\frac{8,475.44}{x} \text {. / Based on the formula } \frac{T(x)}{x}=45 \%-\frac{16,164.53}{x} \text {. }\end{array}$}} \\
\hline $0 / p$ & & & & & \\
\hline
\end{tabular}

Source: own calculation based on $\S 32$ a EStG (German Personal Income Tax Act) in the version of 2016 and 2017. 
The complexity of this tax scale has led to some simplification proposals towards the traditional income tax formula [Kirchhof, 2003; FDP, 2009, p. 6; Rose, 2011, p. 323]. However, rather than the tax scale, the provisions on the calculation of the taxable income contribute to the complexity of the tax system. Furthermore, by means of the formulas included in the German tax scale, a continuous increase of the MTR is (partially) achieved (see Figure 5).

Figure 5 presents the MTR, ATR as well as the amount of the personal income tax in Germany for 2016 and 2017. There are no significant differences between these two consecutive years. The amendment aims to tackle the bracket creep that appears when the nominal increase of the taxable income leads to the application of a higher tax rate, yet does not result in a higher real income (adjusted for inflation). Therefore, the basic allowance as well as the remaining thresholds has been increased (see Table 1, $2^{\text {nd }}$ column).

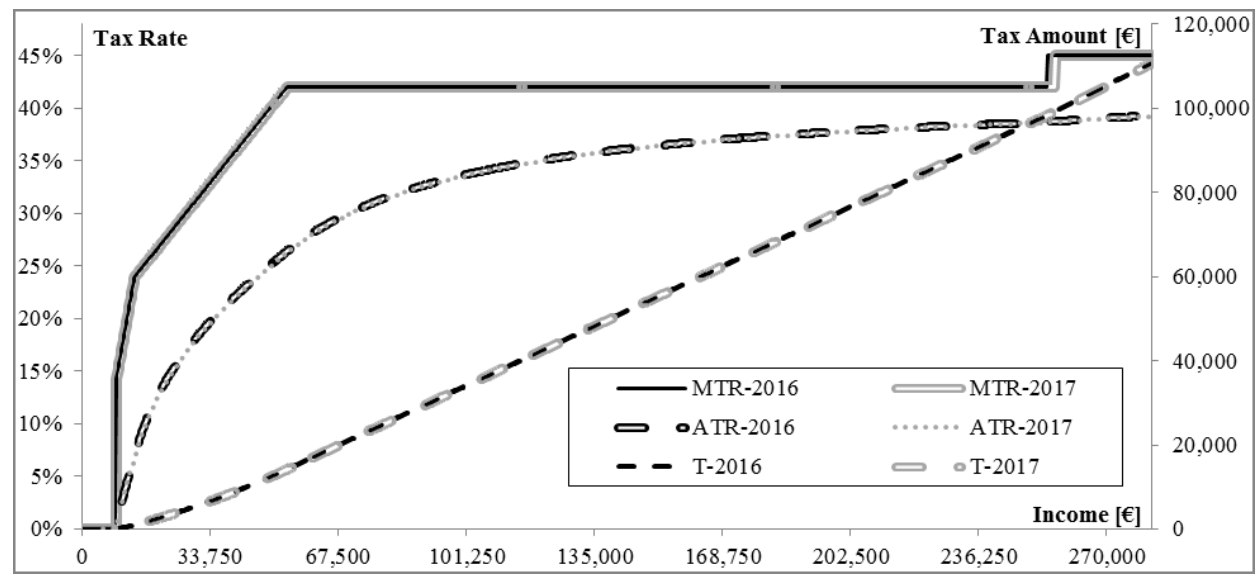

Figure 5. Average tax rate (ATR), marginal tax rate (MTR) and tax amount (T) in Germany for 2016 and 2017

Source: own diagram based on Table 1 .

\section{Polish personal income tax scale}

In contrast to its German counterpart, the Polish tax scale does not contain a linear increasing MTR. Its design follows the most commonly applied scale with constant MTR that rapidly increases for the consecutive tax bracket(s). Table 2 presents the Polish tax scale for 2016 and 2017. 
Pobrane z czasopisma Annales H - Oeconomia http://oeconomia.annales.umcs.pl

Data: 26/04/2023 12:10:27

DESIGNING AND DISPLAYING THE INCOME TAX SCALE UNDER PROGRESSIVITY

Table 2. Polish personal income tax scale

\begin{tabular}{|c|c|c|l|}
\hline \multicolumn{2}{|c|}{ Taxable income in PLN } & \multicolumn{2}{|c|}{ Tax amount } \\
\hline \multirow{2}{*}{ over } & up to & Legal status & \\
\hline \multirow{2}{*}{85,528} & \multirow{2}{*}{85,528} & 2016 & $\mathbf{1 8} \% \cdot \mathbf{x}-556.02$ \\
\cline { 3 - 4 } & & 2017 & $\mathbf{1 8} \% \cdot \mathrm{x}-$ tax credit \\
\cline { 2 - 4 } & & 2016 & $14,839.02+\mathbf{3 2} \% \cdot(x-85,528)$ \\
\cline { 2 - 4 } & & 2017 & $15,395.04+\mathbf{3 2} \% \cdot(x-85,528)-$ tax credit \\
\hline
\end{tabular}

Source: translated table of Art. 27 updof (Polish Personal Income Tax Act) in the version of 2016 and 2017.

The tax scale does not seem to include any relevant changes between 2016 and 2017, although the tax credit amount (see Table 2, the grey marked fields) differs among four intervals and partially depends on the exact amount of the income.

In order to analyse the Polish tax scale, I developed Table 2 by deriving the "hidden" tax brackets (see Table 3). For the purpose of transparency, I propose this form of the tax scale in the tax act (the first three columns of Table 3).

Table 3. Developed Polish personal income tax scale

\begin{tabular}{|c|c|c|c|c|c|}
\hline \multicolumn{3}{|c|}{ Tax brackets [PLN] } & \multirow[t]{2}{*}{$\begin{array}{l}\text { Tax amount } \\
T(x)\end{array}$} & \multirow{2}{*}{$\begin{array}{c}\begin{array}{c}\text { Average tax rate } \\
\text { (ATR) }\end{array} \\
\frac{T(x)}{x} \\
\text { Progressivity } \\
{\left[Y E S \text { if } \frac{d \frac{T(x)}{x}}{d x}>0\right.}\end{array}$} & \multirow{2}{*}{$\begin{array}{l}\text { Marginal tax rate } \\
\underset{(M T R)}{d T(x)} \\
\frac{d x}{}\end{array}$} \\
\hline & over & up to & & & \\
\hline \multicolumn{6}{|c|}{ Legal status 2016} \\
\hline 0 & & $3,091^{\mathrm{a}}$ & 0 & $0 \%$ & $0 \%$ \\
\hline & 091 & 85,528 & $18 \% \cdot x-556.02$ & $\begin{array}{l}(0 \% ; 17 \%\rangle^{\mathrm{b}} \\
{[Y E S]}\end{array}$ & $18 \%$ \\
\hline & 528 & $\infty$ & $32 \% \cdot x-12,529.94^{c}$ & $\begin{array}{l}(17 \% ; 32 \%)^{d} \\
{[Y E S]}\end{array}$ & $32 \%$ \\
\hline \multicolumn{6}{|c|}{ Legal status 2017} \\
\hline 0 & & $6,600^{\mathrm{e}}$ & 0 & $0 \%$ & $0 \%$ \\
\hline & 600 & 11,000 & $32.36 \% \cdot x-2,135.97^{f}$ & $\begin{array}{c}(0 \% ; 13 \%)^{g} \\
{[Y E S]}\end{array}$ & $32.36 \%$ \\
\hline &, 000 & 85,528 & $18 \% \cdot x-556.02$ & $\begin{array}{l}\langle 13 \% ; 17 \%)^{\mathrm{h}} \\
{[Y E S]}\end{array}$ & $18 \%$ \\
\hline &, 528 & 127,000 & $33.34 \% \cdot x-13,676.61^{i}$ & $\begin{array}{l}\langle 17 \% ; 23 \%)^{j} \\
{[Y E S]}\end{array}$ & $33.34 \%$ \\
\hline & 7,000 & $\infty$ & $32 \% \cdot x-11,973.92^{k}$ & $\begin{array}{c}\langle 23 \% ; 32 \%)^{1} \\
{[Y E S]}\end{array}$ & $32 \%$ \\
\hline $\mathrm{a}$ & \multicolumn{5}{|c|}{$\begin{array}{l}\text { The basic allowance is derived from the first tax bracket for an income of up to PLN } 85,528 \text {, within which the tax amount } \\
\text { is calculated as follows: } M A X[18 \% \cdot \mathrm{x}-556.02 ; 0] \text {, whereby the original formula does not include the MAX function } \\
\text { and thus provides negative values for an income below the basic allowance. After considering the rounding off, the basic } \\
\text { allowance is } \mathrm{x}=\frac{556.02+0.5}{18 \%}=3,091 \text {. }\end{array}$} \\
\hline $\mathrm{b}$ & \multicolumn{5}{|c|}{ Based on the formula $\frac{T(x)}{x}=18 \%-\frac{556.02}{x}$. } \\
\hline$c$ & \multicolumn{5}{|c|}{$\begin{array}{l}\text { Based on the following formula } 14,839.02+32 \% \cdot(x-85,528) \text { according to Article } 27 \text { para. } 1 \text { of the Polish Personal } \\
\text { Income Tax Act. }\end{array}$} \\
\hline d & \multicolumn{5}{|c|}{ Based on the formula $\frac{T(x)}{x}=32 \%-\frac{12,529.94}{x}$} \\
\hline e & \multicolumn{5}{|c|}{$\begin{array}{l}\text { The basic allowance is derived from the first tax bracket for an income of up to PLN } 85,528 \text {, within which the tax amount } \\
\text { is calculated as follows: } \operatorname{MAX}[18 \% \cdot \mathrm{x}-1,188 ; 0] \text {, whereby the tax allowance of } 1,188 \text { applies for an income up to PLN } \\
6,600 \text {. }\end{array}$} \\
\hline $\mathrm{f}$ & \multicolumn{5}{|c|}{$\begin{array}{l}\text { Based on the following formula } 18 \% \cdot x-\left[1,188-\frac{631.98 \cdot(x-6,600)}{4,400}\right] \text { ac } \\
\text { Personal Income Tax Act. }\end{array}$} \\
\hline
\end{tabular}




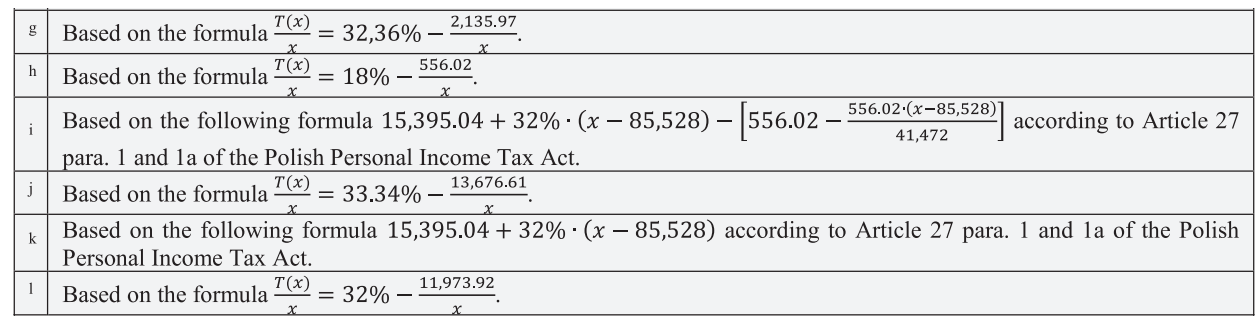

Source: own calculation based on Art. 27 updof (Polish Personal Income Tax Act) in the version of 2016 and 2017.

The developed tax scale reveals the significant increase of the basic allowance from PLN 3,091 to PLN 6,600. This is due to the judgement of the Polish Constitutional Court [Trybunał Konstytucyjny, 2015] according to which the lack of a mechanism to guarantee that at least the minimum subsistence level is exempt from taxation is unconstitutional. However, the increase in the basic allowance has not been accompanied by an adjustment of the whole tax scale and thus the threshold of PLN 85,528 for the highest MTR of $32 \%$ has remained unchanged. It is noteworthy that the developed tax scale reveals more MTR intervals for 2017 (see Table 3, last column and Figure 6). Moreover, the introduced MTR for the second and fourth tax bracket are higher than the MTR for the consecutive income interval, respectively (see Figure 6, MTR-2017). A progressive tax does not imply a non-decreasing MTR function. Due to the increasing ATR, the amended tax scale fulfils the condition of progressivity (see Figure 6, ATR-2017). Nevertheless, it appears strange that the low income right above the basic allowance is subject to the relatively high MTR of $32.36 \%$.

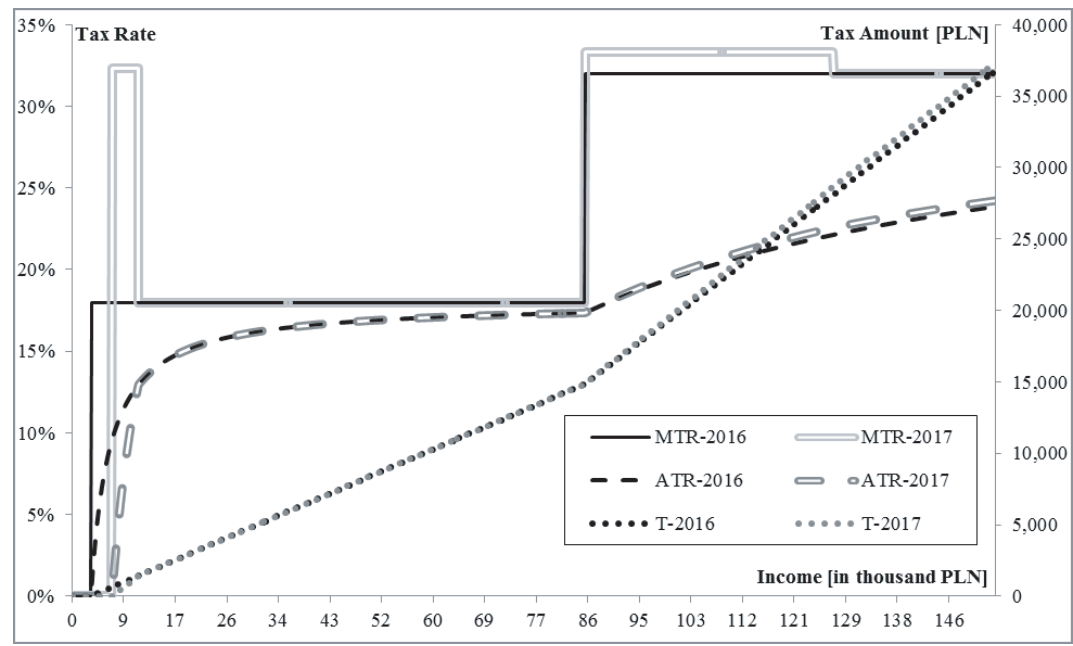

Figure 6. Average tax rate (ATR), marginal tax rate (MTR) and tax amount (T) in Poland for 2016 and 2017

Source: own diagram based on Table 3 . 
This phenomenon is caused by the decreasing tax credit amount for a higher income. While under the 2016 legal status the basic allowance is provided for every income, the introduced variable tax credit reduces the benefit of the basic allowance that effectively is not granted for individuals with a taxable income over PLN 127,000. This leads to a higher tax burden in 2017 for incomes above the threshold of PLN 85,528 (see Figure 6, T-2016 vs. T-2017).

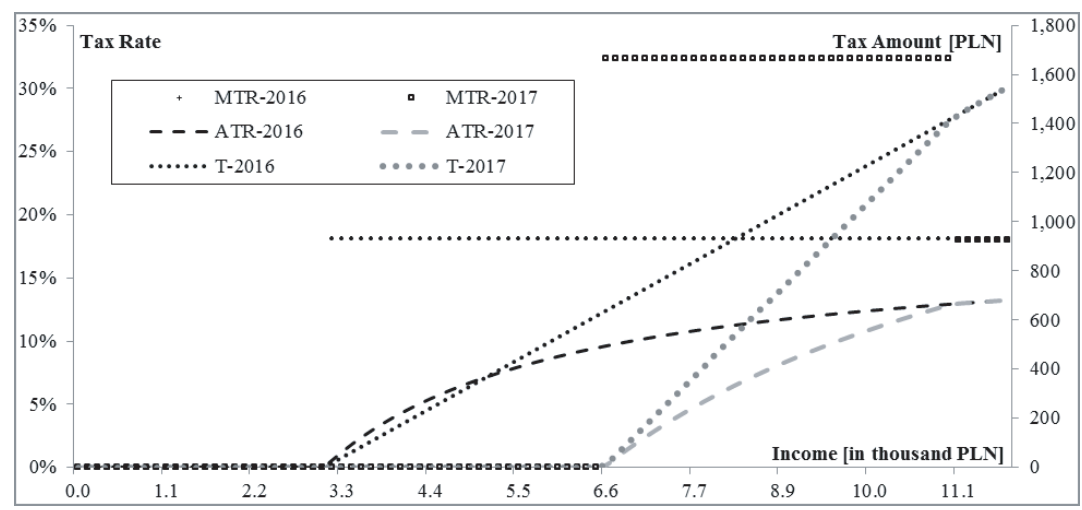

Figure 7. Average tax rate (ATR), marginal tax rate (MTR) and tax amount (T) on low income in Poland for 2016 and 2017

Source: own diagram based on Table 3 .

A closer look at the tax rates for a lower income (see Figure 7) clarifies the objective of the Polish legislator to only provide the tax relief for low earners. In order to achieve the same tax burden for a taxable income from PLN 11,000 before and after the amendment, the tax amount as well as the ATR rapidly increase within the income interval between the basic allowance (of PLN 6,600) and PLN 11,000 (see Figure 7, T-2017 and ATR-2017). This leads to the aforementioned unusual high MTR of $32.36 \%$, which may have a negative impact on the incentive to work.

\section{4. "Bubbles" in the British and the US tax system}

The up and down of the MTR (commonly known as a "bubble") is not a new concept of the Polish legislator; rather, the amendment of the tax scale in Poland is based on the British tax system, which essentially provides a personal allowance of $£ 11,000$. However, this allowance is phased out for an income over $£ 100,000$, declining by $£ 1$ for every $£ 2$ of income above this threshold and thus within the interval $x \in(100,000 ; 122,000)$. At such a level, the income is subject to the "higher rate" of $40 \%$ and the MTR can be derived as follows: $\operatorname{MTR}(x)=\frac{d T(x)}{d x}=\frac{d\{40 \% \cdot[x-(11,000-0.5 \cdot(x-100,000))]+T(100,000)\}}{d x}=60 \%$ [HM Revenue \& Customs, 2016]. This MTR exceeds the consecutive MTR (on a higher 
income) and thus creates a bubble (see Figure 8). However, this bubble applies for a significantly higher income than its Polish counterpart.

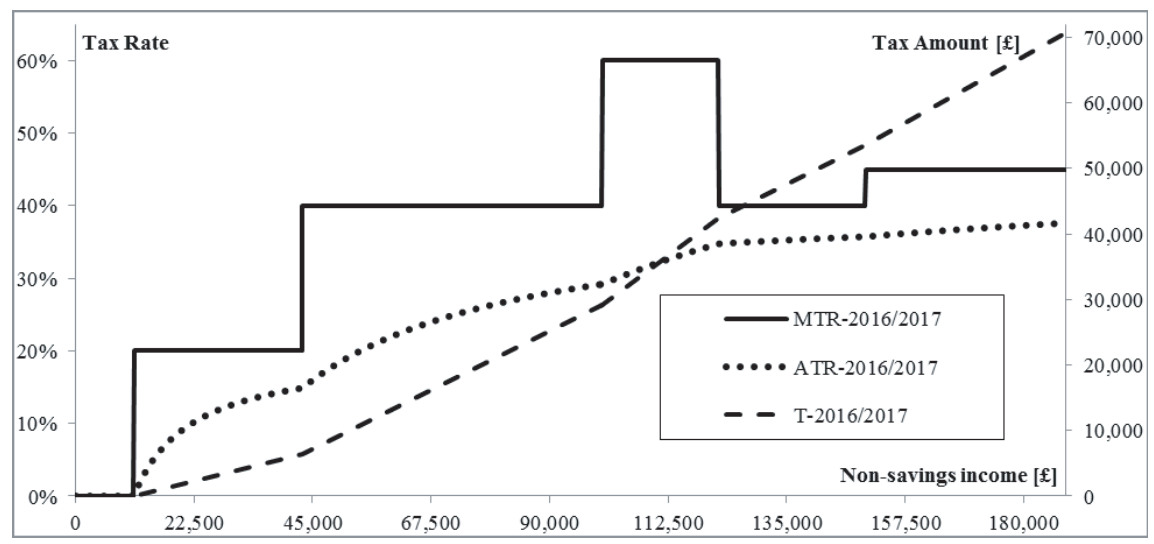

Figure 8. Average tax rate (ATR), marginal tax rate (MTR) and tax amount (T) in the UK for the $2016 / 2017$ tax year

Source: own diagram based on information provided by [HM Revenue \& Customs, 2016; IBFD, 2016a, pp. 1096-1097].

The phenomenon of tax bubbles also appears in the US tax law. The baseline corporate tax rate of $35 \%$ is exceeded by the MTR of $39 \%$ and $38 \%$ for two income intervals $(100,000 ; 335,000)$ and $(15,000,000 ; 18,333,333)$, respectively [PWC, 2016, p. 47]. These two bubbles aim to eliminate the benefit of the reduced tax rates applied for the lower income. Figure 9 illustrates the approximation of the ATR and MTR within the bubble intervals.

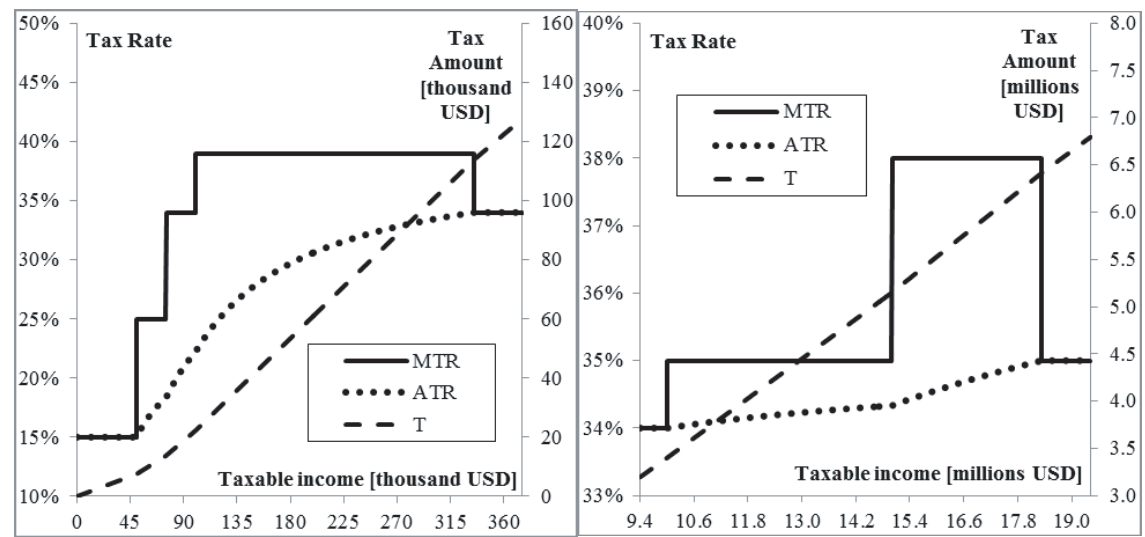

Figure 9. Average tax rate (ATR), marginal tax rate (MTR) and tax amount (T) in the USA for the 2016 tax year

Source: own diagram based on information provided by [PWC, 2016, p. 47]. 
To conclude, the bubbles as an income interval with a higher MTR than the MTRs applied for a lower and higher income around the bubble are used to eliminate tax benefits for a higher income. However, the presented first bubble in the Polish tax scale applies for a relatively low income and thus may negatively affect the willingness to work.

\section{5. "Bubbles" and the joint taxation}

The joint taxation provides tax benefits that result from the progressivity of the tax scale. Under this taxation form, the tax burden for married couples is usually computed as the double tax amount calculated for half of the aggregate income of both spouses. Thereby, the tax benefit (TB) can be calculated by means of the formula $T B=T\left(x_{1}\right)+T\left(x_{2}\right)-2 \cdot T\left(\frac{x_{1}+x_{2}}{2}\right)$, where $x_{1}, x_{2}$ denote the income of one spouse and the other, respectively. $T(x)$ is the tax amount for a taxable income of $x$.

Assuming that $x_{1}<x_{2}$, the tax advantage is equal to the difference of the tax reduction regarding the higher income spouse and the tax increase for the other spouse $T B=\left[T\left(x_{2}\right)-T\left(\frac{x_{1}+x_{2}}{2}\right)\right]-\left[T\left(\frac{x_{1}+x_{2}}{2}\right)-T\left(x_{1}\right)\right]$. The joint taxation (or income splitting) can be interpreted as a transfer of the taxable income from one spouse to the other (unit by unit) until the incomes are equalised $\left(x_{1}=x_{2}\right)$. With this in mind, the tax benefit can be calculated by means of the MTR as follows:

$$
T B=\sum_{i=0}^{x_{2}} \operatorname{MTR}\left(\frac{x_{1}+x_{2}}{2}+i\right)-\sum_{i=0}^{\frac{x_{1}+x_{2}}{2}} \operatorname{MTR}\left(x_{1}+i\right)
$$

The joint taxation is advantageous if the MTR constitutes a non-decreasing function (see Figure 10), which implies a progressive tax scale. However, a progressive tax scale - in other words, an increasing ATR - does not imply a non-decreasing MTR.

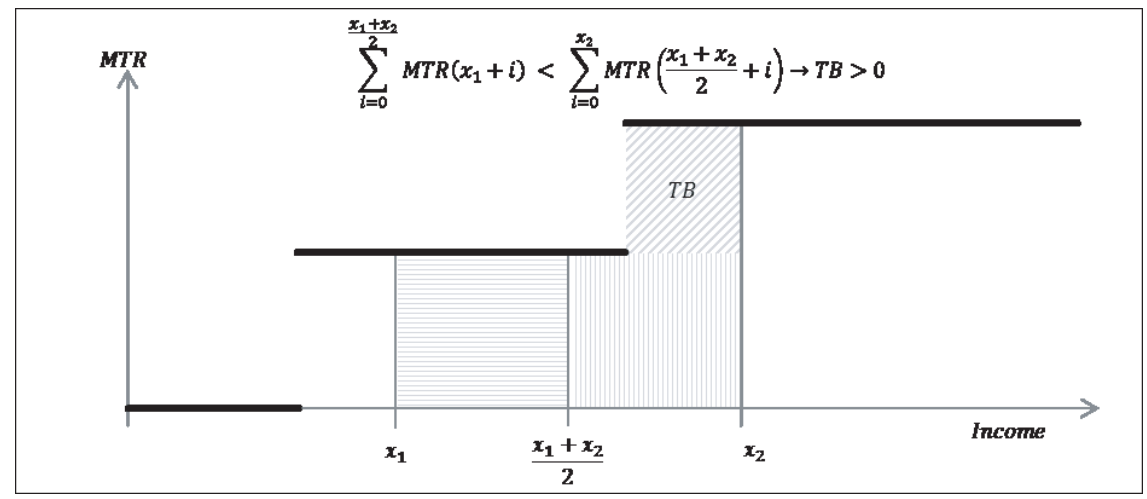

Figure 10. Tax benefit (TB) from the joint taxation under a non-decreasing MTR 
A bubble in the MTR function eliminates its non-decreasing character but not the tax progressivity, as long as $\operatorname{MTR}\left(\mathrm{x}^{*}\right) \geq \operatorname{ATR}\left(\mathrm{x}^{*}\right)$ for $\mathrm{x}^{*} \epsilon\langle 0 ; \infty)$. Interestingly, such a bubble breaks the principle that the tax burden under income splitting cannot be higher compared to separate taxation [Endres, Spengel, 2015, p. 84]. Figure 11 shows that the joint taxation in case of a bubble in the MTR function could lead to a higher tax burden.

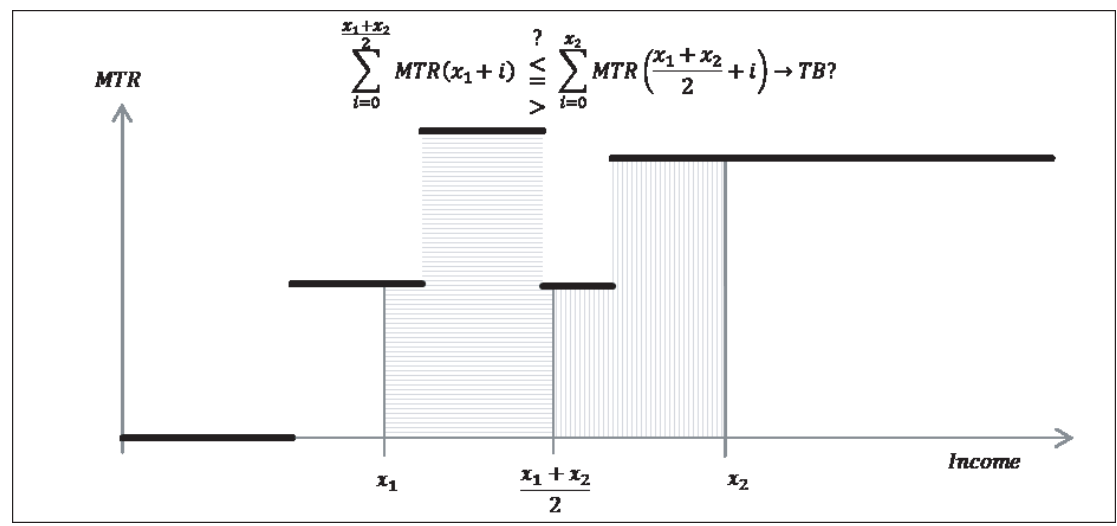

Figure 11. Tax benefit (TB) from the joint taxation in case of MTR bubble

Source: own diagram.

This phenomenon can be demonstrated by means of the Polish tax scale. Table 4 presents the tax advantage from the income splitting for a chosen case of a marriage couple. Due to the introduced MTR bubbles, the tax benefit of PLN 74 under the 2016 legal status turns into the additional tax burden of PLN 482 for 2017 and thus the joint taxation is disadvantageous.

Table 4. Tax benefit (TB) from the joint taxation in Poland

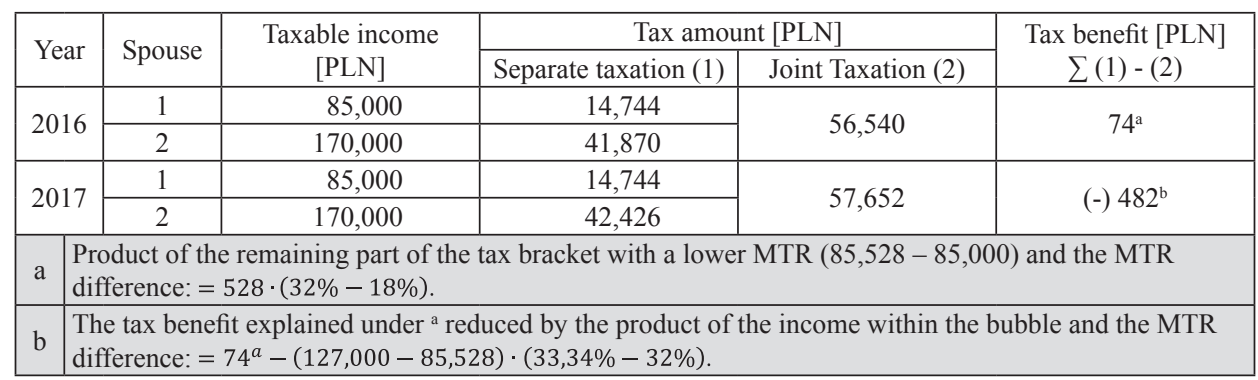

Source: own calculations based on information provided in Table 2 and 3. 


\section{Conclusions}

A linear increasing MTR is an appropriate approach to avoid rapid MTR as well as ATR hikes. While one could argue that this method leads to a more complex tax function, regarding the tax transparency, the determination of the taxable income rather than the tax function provides the scope for simplification.

Instead, the Polish legislator has introduced the so-called bubbles in the form of increased MTR. This feature excludes high income from the basic allowance or reduced tax rates and is known in other countries like the UK and the USA. However, in Poland, the first bubble (MTR above 32\%) applies for a relatively low income right above the basic allowance and may negatively affect the willingness to work. Furthermore, the bubbles may lead to a higher tax burden under joint taxation compared to separate taxation and thereby constitute an unexpected result under a progressive tax.

\section{Bibliography}

Deutscher Bundestag, Gesetzentwurf der Fraktionen der CDU/CSU und FDP, Entwurf eines Steuerreformgesetzes 1990, Drucksache 11/2157, 1988.

Endres D., Spengel C., International Company Taxation and Tax Planning, Kluwer Law International, 2015.

FDP, Die Mitte stärken, Deutschlandprogramm 2009, Programm der Freien Demokratischen Partei zur Bundestagswahl 2009.

HM Revenue \& Customs, Income Tax rates and allowances: current and past, 2016, www.gov.uk [access: 03.04.2016].

IBFD, European Tax Handbook 2016, Amsterdam 2016a.

IBFD, Global Individual Tax Handbook 2016, Amsterdam 2016b.

Johansen L., Public Economics, Amsterdam 1965.

Kirchhof P., Einkommensteuergesetzbuch - Ein Vorschlag zur Reform der Einkommen- und Körperschaftsteuer, 2003.

PWC, Worldwide Tax Summaries, Corporate Taxes 2016/17, Country chapters, North America, United States 2016, pp. 46-66.

Rose M., Vorschlag für eine Reform des Einkommensteuertarifs, „Wirtschaftsdienst“ 2011, Nr 5 , DOI: https://doi.org/10.1007/s10273-011-1225-7, pp. 323-327.

Seidl C., Pogorelskiy K., Traub S., Tax Progression in OECD Countries. An Integrative Analysis of Tax Scales and Income Distributions, Springer 2013, DOI: https://doi.org/10.1007/978-3-642-28317-8.

Seidl C., Topritzhofer E., Grafendorfer W., An Outline of a Theory of Progressive Individual Income-Tax Functions, "Zeitschrift für Nationalökonomie/Journal of Economics" 1970, Vol. 30, No. 3/4,

DOI: https://doi.org/10.1007/BF01289246, pp. 407-429.

Trybunał Konstytucyjny/Polish Constitutional Court (2015) judgment of 28 October 2015 in Case K 21/14. Voigt A., Mathematische Theorie des Tarifwesens; Grundlagen der Kritik der Abgaben- und Preis-Tarife mit besonderer Berücksichtigung des preussichen Einkommensteuertarifs, Fisher, Jena 1912. 


\section{Ksztaltowanie i zobrazowanie progresywnej skali podatkowej}

Większość państw stosuje progresywną skalę do opodatkowania dochodu osób fizycznych. W niniejszym artykule został omówiony zróżnicowany kształt progresywnej taryfy podatkowej ze szczególnym uwzględnieniem podwyższonej krańcowej stopy podatku, która wynika z wykluczenia podatników o wyższym dochodzie z zastosowania preferencji podatkowych $\mathrm{w}$ formie kwoty wolnej czy też obniżonej stopy podatkowej. Sytuacja taka może prowadzić do wyższego obciążenia podatkowego małżonków, którzy się wspólnie rozliczają. Analizę oparto na skalach podatkowych w Niemczech, Polsce, Wielkiej Brytanii oraz USA.

\section{Designing and Displaying the Income Tax Scale under Progressivity}

In most countries, a progressive tax is levied on the income of individuals. This article addresses the different design of a progressive tax scale taking into account the issue of the so-called tax bubbles that constitute an increased MTR. This feature of the tax function is a result of the exclusion of the high income taxpayers from the basic allowance or reduced tax rates. As shown in the article, this may lead to a higher tax burden under the joint taxation compared to the separate taxation. The analysis refers to the tax scales in Germany, Poland, the UK and the USA. 